\title{
EFEKTIFITAS MODEL PEMBELAJARAN KOOPERATIF TIPE PICTURE AND PICTURE TERHADAP KEMAMPUAN MENULIS TEKS BERITA EFEKTIFITAS MODEL PEMBELAJARAN KOOPERATIF TIPE PICTURE AND PICTURE TERHADAP KEMAMPUAN MENULIS TEKS BERITA KELAS VII MTS AL-IKHLAS PEMETUNG BASUKI
}

\author{
Ari Setiyanto $^{1^{*}}$, M. A Nurkholis ${ }^{2}$ \\ ${ }^{1}$ Dosen Sekolah Tinggi Ekonomi Dan Bisnis Islam Darussalam OKI \\ ${ }^{2}$ Dosen Sekolah Tinggi Ekonomi Dan Bisnis Islam Darussalam OKI
}

arisetiyanto27@gmail.com

Anwarnurkholis28@gmail.com

\begin{abstract}
Abstrak
Pengajaran keterampilan bahasa dan sastra Indonesia mencakup dalam beberapa keterampilan di antaranya keterampilan mendengarkan, keterampilan membaca, keterampilan berbicara, dan keterampilan menulis. Dalam pembelajaran menulis, khususnya menulis teks berita, selama ini peserta didik tidak cukup diberikan penjelasan tentang teori menulis saja, tetapi hal-hal yang berhubungan dengan masalah kebahasaan, ejaan dan pilihan kata serta teknik penulisan juga harus diperhatikan. Berdasarkan dalam menulis teks berita, peserta didik sering merasa kesulitan menyampaikan unsur-unsur berita dalam teks berita. Penelitian ini bertujuan untuk mendeskripsikan efektivitas model pembelajaran kooperatif tipe picture and picture terhadap kemampuan menulis teks berita peserta didik kelas VII MTs Al-Ikhlas Pemetung Basuki. Pendekatan yang digunakan dalam penelitian ini adalah pendekatan kuantitatif dengan rancangan Posttest Only Control Design dan uji hipotesis yaitu menggunakan rumus Polled Varians dengan bantuan Microsoft exel 2007. Berdasarkan tabel Microsoft excel 2007 pada tabel 4.8 harga thitung dibandingkan tabel dengan taraf signifikan $5 \%$ dari data tersebut dapat dilihat harga thitung lebih besar dari harga tabel $(7.14>1.67)$. Dengan demikian $\mathrm{H}_{\mathrm{a}}$ diterima dan $\mathrm{H}_{0}$ ditolak. Dengan demikian dapat disimpulkan bahwa $\mathrm{H}_{\mathrm{a}}$ ditolak atau $\mathrm{Ho}$ diterima yang berarti menulis teks berita peserta didik yang diajar dengan model pembelajaran kooperatif tipe picture and picture lebih efektif. Penelitian ini dapat disimpulkan bahwa model pembelajaran kooperatif tipe picture and picture efektif dalam pembelajaran menulis teks berita kelas VII yang tercermin dalam skor atau nilai post-test.
\end{abstract}

Kata kunci : Menulis teks berita, model pembelajaran kooperatif, tipe picture and picture.

\section{PENDAHULUAN}

Keterampilan menulis merupakan suatu keterampilan yang paling akhir dikuasai setelah kemampuan menyimak, berbicara, dan membaca. Menurut Tarigan (2008:3) menyatakan bahwa menulis merupakan suatu kegiatan yang produktif dan ekspresif. Kegiatan menulis, penulis harus memanfaatkan grafologi, struktur bahasa, dan kosakata. Ketentuan dalam fungsi utama menulis adalah sebagai alat komunikasi yang tidak langsung. Menurut Tarigan (2008:22) menulis sangat penting bagi pendidikan karena memudahkan pelajar berpikir, menolong kita berpikir kritis, memudahkan merasakan dan menikmati hubungan-hubungan, memperdalam tanggap atau persepsi kita, memecahkan masalah-masalah yang kita hadapi dan menyusun urutan bagi pengalaman.

Pembelajaran menulis merupakan suatu kegiatan yang diajarkan secara terus-menerus kepada peserta didik. Tanpa latihan terus-menerus, kegiatan menulis kegiatan menulis tidak dapat berjalan dengan baik. Kegiatan menulis bukan merupakan kegiatan yang linier tetapi bersifat rekursif, artinya kegiatan menulis dilakukan berulang-ulang, diperlukan perbaikan, dan tidak langsung sekali jadi. Akan tetapi, dalam kenyataannya tujuan pembelajaran menulis belum dicapai secara maksimal oleh peserta didik.

Mills (dalam Suprijono, 2009:45) mengatakan bahwa model adalah interpretasi terhadap hasil observasi dan pengukuran yang diperoleh dari beberapa sistem. Model pembelajaran merupakan landasan praktik pembelajaran hasil penurunan teori psikologi pendidikan dan teori belajar yang dirancang berdasarkan analisis terhadap implementasi kurikulum dan implikasinya pada tingkat operasional di kelas. Model pembelajaran dapat diartikan juga sebagai pola yang digunakan untuk menyusun kurikulum, mengatur materi dan memberi petunjuk kepada guru di kelas. Sedangkan Suprijono (2009:45) mengatakan model pembelajaran adalah pola yang digunakan sebagai pedoman dalam merencanakan pembelajaran di 
EFEKTIFITAS MODEL PEMBELAJARAN KOOPERATIF TIPE PICTURE .... $\mid 9$ kelas maupun tutorial. Menurut Arends (dalam Suprijono, 2009:46) mengatakan bahwa model pembelajaran mengacu pada pendekatan yang akan digunakan, termasuk di dalamnya tujuan-tujuan pembelajaran, tahaptahap dalam kegiatan pembelajaran, lingkungan pembelajaran, dan pengelolaan kelas.

Menurut Joyce (dalam Trianto, 2007:5) model pembelajaran adalah suatu perencanaan atau suatu pola yang digunakan sebagai pedoman dalam merencanakan pembelajaran di kelas atau pembelajaran dalam tutorial dan untuk menentukan perangkat-perangkat pembelajaran di dalam buku-buku, film, komputer, dan lain-lain. Menurut para ahli di atas dapat disimpulkan bahwa model pembelajaran adalah perencanaan pembelajaran yang dilakukan sebagai acuan dalam melaksanakan kegiatan pembelajaran di kelas baik dari langkah-langkah pembelajaran, media dan evaluasi pembelajaran.

Sedangkan yang dimaksud model pembelajaran kooperatif (Cooperative Learning) adalah pendekatan pembelajaran yang secara sadar dan sistematis mengembangkan interaksi yang silih asah, dan silih asuh antar peserta didik sebagai latihan hidup didalam masyarakat nyata. Menurut Hamdani (2011:30) mengatakan model pembelajaran kooperatif adalah rangkaian kegiatan belajar peserta didik dalam kelompok tertentu untuk mencapai tujuan pembelajaran yang dirumuskan. Dalam pembelajaran kooperatif diterapkan strategi belajar dengan sejumlah peserta didik sebagai anggota kelompok kecil yang tingkat kemampuannya berbeda.

Pembelajaran kooperatif perlu ditanamkan kepada peserta didik agar pembelajaran kooperatif dalam berjalan lebih efektif. Adapun berbagai elemen dalam pembelajaran kooperatif adalah sebagai berikut; peserta didik harus memiliki persepsi sama bahwa mereka "tenggelam" atau "berenang" bersama, peserta didik memiliki tanggung jawab terhadap tiap peserta didik lain dalam kelompoknya, di samping tanggung jawab terhadap diri sendiri dalam mempelajari materi yang dihadapi, peserta didik harus berpandangan bahwa mereka semuanya memiliki tujuan yang sama, peserta didik harus membagi tugas dan berbagi tanggung jawab sama besarnya diantara para anggota kelompok, peserta didik akan diberikan satu evaluasi atau penghargaan yang akan ikut berpengaruh terhadap evaluasi seluruh anggota kelompok, peserta didik berbagi kepemimpinan sementara mereka memperoleh keterampilan bekerjasama selama belajar, dan peserta didik akan diminta mempertanggungjawabkan secara individual materi yang ditangani dalam kelompok kooperatif.

Menurut Sholeh (2011:217) model pembelajaran kooperatif tipe picture and picture adalah salah satu metode pembelajaran aktif yang menggunakan gambar dan dipasangkan atau diurutkan menjadi urutan yang sistematis, seperti menyusun gambar secara berurutan, menunjukkan gambar. Adanya gambar-gambar yang berkaitan dengan materi belajar peserta didik lebih aktif dan dapat tercapai tujuan akhir dari proses pembelajaran. Operasionalnya alat bantu atau media gambar dipasangkan satu sama lain atau diurutkan menjadi urutan yang logis dan diharapkan peserta didik mampu mengikuti pelajaran dengan baik.

Menurut Sholeh (2011:217) terdapat beberapa prinsip dasar dalam model pembelajaran kooperatif tipe picture and picture antara lain; anggota kelompok (peserta didik) bertanggung jawab atas segala sesuatu yang dikerjakan dalam kelompoknya, anggota kelompok (peserta didik) harus mengetahui bahwa semua anggota kelompok mempunyai tujuan yang sama, anggota kelompok (peserta didik) harus membagi tugas dan tanggung jawab yang sama di antara anggota kelompoknya, anggota kelompok (peserta didik) akan dikenai evaluasi, anggota kelompok (peserta didik) berbagi kepemimpinan dan membutuhkan keterampilan untuk belajar bersama selama proses belajarnya, dan anggota kelompok (peserta didik) akan diminta mempertanggungjawabkan secara individual materi yang ditangani dalam kelompok kooperatif. Masih menurut pendapat yang sama langkah-langkah dari pelaksanaan model pembelajaran kooperatif tipe picture and picture adalah sebagai berikut; guru menyampaikan tujuan pembelajaran atau kompetensi yang ingin dicapai, guru menyajikan materi pengantar sebagai pengantar, guru menampilkan atau memperlihatkan gambar-gambar kegiatan berkaitan dengan materi, guru menunjuk atau memanggil peserta didik secara bergantian untuk memasang atau mengurutkan gambar-gambar menjadi urutan yang logis, guru menanyakan alasan atau dasar pemikiran dari urutan gambar, dari alasan atau urutan tersebut guru mulai menanamkan konsep materi yang sesuai dengan kompetensi yang ingin dicapai, dan guru memberi kesimpulan atau rangkuman dari materi yang baru saja dibahas.

Kelebihan model pembelajaran kooperatif tipe picture and picture antara lain; guru lebih mengetahui kemampuan peserta didik masing-masing, melatih berfikir logis dan sistematis, peserta didik dibantu belajar berfikir berdasarkan sudut pandang suatu subjek bahasan dengan menggunakan kebebasan peserta didik dalam praktik berfikir, motivasi peserta didik untuk belajar semakin dikembangkan, dan peserta didik dilibatkan dalam perencanaan dan pengelolaan kelas. 
Sedangkan kelemahan model pembelajaran kooperatif tipe picture and picture adalah memakan banyak waktu, banyak peserta didik yang pasif, munculnya kekhawatiran akan terjadi kekacauan di kelas, adanya beberapa peserta didik tertentu yang terkadang tidak senang jika disuruh bekerjasama dengan orang lain, dan kebutuhan akan dukungan fasilitas, alat, dan biaya yang cukup memadai.

Adapun langkah-langkah yang ditempuh oleh penulis dalam model pembelajaran kooperatif tipe picture and picture ini adalah sebagai berikut; guru menyampaikan kompetensi menulis teks berita, dilanjutkan guru menyajikan materi teks berita, menunjukkan/memperlihatkan gambar-gambar kegiatan berkaitan dengan tema kecelakaan, guru menunjuk peserta didik secara bergantian untuk mengurutkan gambar-gambar secara logis, guru menanyakan alasan/dasar pemikiran urutan gambar tersebut. Dari alasan/urutan gambar tersebut guru memulai menanamkan konsep/materi menulis teks berita. Peserta didik mulai menulis teks berita dari gambar yang sudah di urutkan secara logis dengan memperhatikan unsurunsur berita, dan terakhir guru memberikan kesimpulan atau rangkuman dari materi menulis teks berita.

\section{METODE PENELITIAN}

Rancangan desain penelitian ini menggunakan Posttest Only Control Design. Desain ini terdapat dua kelompok yang masing-masing dipilih secara random/R. Kelompok pertama diberi perlakuan $(\mathrm{X})$ dan kelompok yang lain tidak. Kelompok yang diberi perlakuan disebut kelompok eksperimen dan kelompok yang tidak diberi perlakuan disebut kelompok kontrol. Pengaruh adanya perlakuan (treatment) adalah $\left(\mathrm{O}_{1}\right.$ : $\mathrm{O}_{2}$ ).

Variabel ini melibatkan dua variabel yaitu penggunaan model pembelajaran kooperatif tipe picture and picture terhadap kemampuan menulis teks berita sebagai variabel bebas dan kemampuan menulis teks berita peserta didik yang tidak diberi perlakuan sebagai variabel terikat. Penentuan variabel dalam penelitian ini dapat dilihat pada gambar berikut;

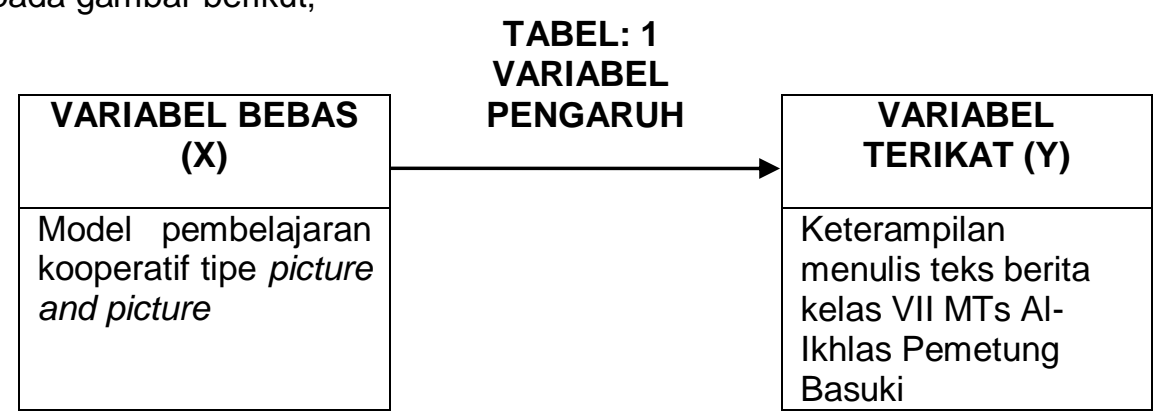

Penelitian ini menggunakan teknik analisis dengan menggunakan uji-t dan menggunakan rumus Polled Varians ini dimaksudkan untuk mencari keefektifan model pembelajaran kooperatif tipe picture and picture dalam menulis teks berita. Data yang dianalisis dalam penelitian ini adalah data sesudah penelitian. Data sesudah penelitian yaitu hasil post-test setelah sampel diberi perlakuan di kelas eksperimen dan kelas kontrol digunakan untuk mengetahui perbedaan dengan hasil post-test dari pembelajaran menulis teks berita di kelas eksperimen dan kelas kontrol.

\section{HASIL DAN PEMBAHASAN}

\section{HASIL}

Analisis pada instrument penelitian ini dilakukan untuk mengetahui tolak ukur apakah soal dapat diujikan kepada peserta didik. Hasil analisis dapat diketahui dengan uji reliabilitas dan uji validitas yang sebelumnya peneliti memberikan lembar validasi kepada para pakar, sehingga dapat diketahui kevalidan sebuah instrument tes menulis teks berita tersebut. Kemudian uji reabilitas instrument dalam penelitian ini dapat diketahui dengan tekhnik alfa cronbach.

Hasil perhitungan reliabilitas menggunakan rumus Alfa Cronbach diperoleh reliabilitas instrumen diketahui bahwa $r_{\text {hitung }}$ lebih besar dari $r_{\text {tabel }}$ untuk taraf kesalahan $1 \%$ maupun $5 \%$ dengan rincian $r_{\text {hitung }} 6.684$ lebih besar dari $r_{\text {tabel }}$ yaitubdengan taraf $1 \% 0.505$ dan dengan taraf $5 \% 0.396(6.684>0.505>0.396)$, maka dapat dikatakan instrument kemampun menulis berita tersebut reliabel dan dapat dipergunakan sebagai alat penelitian.

Hasil perhitungan Microsoft excel 2007 didapat bahwa varians kelas eksperimen sebesar $=50.08$ dan varians kelas kontrol sebesar 157.66. jadi $F=50.08: 157.66=0.31$. harga $F_{\text {hitung }}$ tersebut perlu dibandingkan dengan $F_{\text {tabel }}$ dengan $\mathrm{dk}$ pembilang $=(35-1)$ dan dk penyebut $=35-1$. Berdasarkan $\mathrm{dk}$ pembilang 24 dan penyebut 24 dengan taraf kesalahan $5 \%$ maka harga $F_{\text {tabel }} 0.55$. harga $F_{\text {hitung }}$ lebih kecil dari $\mathrm{F}_{\text {tabel }}(0.31<0.55)$. dengan demikian $\mathrm{H}_{0}$ diterima dan $\mathrm{H}_{\mathrm{a}}$ ditolak. Hal ini berarti menunjukkan varian homogen.

Hasil uji hipotesis, harga $t_{\text {hitung }}$ dibandingkan $t_{\text {tabel }}$ dengan taraf signifikan $5 \%$ dari data tersebut dapat 
EFEKTIFITAS MODEL PEMBELAJARAN KOOPERATIF TIPE PICTURE .... $\mid 11$ dilihat harga $t_{\text {hitung }}$ lebih besar dari harga $t_{\text {tabel }}(7.14>1.67)$. Dengan demikian $\mathrm{H}_{\mathrm{a}}$ diterima dan $\mathrm{H}_{0}$ ditolak. Maka dapat disimpulkan bahwa pembelajaran dengan menggunakan model pembelajaran kooperatif tipe picture and picture dalam keterampilan menulis teks berita lebih efektif dibandingkan dengan menulis berita tanpa menggunakan model pembelajaran kooperatif tipe picture and picture.

\section{PEMBAHASAN}

Pembelajaran picture and picture adalah salah satu metode pembelajaran aktif yang menggunakan gambar dan dipasangkan atau diurutkan menjadi urutan yang sistematis, seperti menyusun gambar secara berurutan. Proses pembelajaran dengan adanya gambar-gambar yang berkaitan dengan materi belajar peserta didik lebih aktif dan dapat tercapai tujuan akhir dari proses pembelajaran. Menurut Ahmadi (2011:58) picture and picture adalah suatu metode belajar yang menggunakan gambar dan dipasangkan atau diurutkan menjadi urutan logis. Picture and picture ini berbeda dengan media gambar dimana picture and picture berupa gambar yang belum disusun secara berurutan hal ini digunakan oleh peserta didik, sedangkan media gambar berupa gambar utuh digunakan oleh guru dalam proses pembelajaran. Proses pembelajaran dengan adanya penyusunan gambar guru dapat mengetahui kemampuan peserta didik dalam memahami konsep materi dan melatih berfikir logis dan sistematis.

Hasil penelitian menunjukkan bahwa pembelajaran menulis berita dengan model pembelajaran kooperatif tipe picture and picture pada kelompok eksperimen lebih baik dibandingkan dengan kelompok kontrol. Hal ini sesuai dengan pendapat Tarigan (2008:22) mengatakan fungsi utama menulis adalah sebagai alat komunikasi tidak langsung. Berdasaarkan hasil yang diperoleh skor rata-rata menulis teks berita kelas eksperimen adalah 78.82 dan kelas kontrol 61.17. Hal ini menunjukkan bahwa hasil menulis teks berita di kelompok eksperimen, yaitu peserta didik yang belajar dengan model pembelajaran kooperatif tipe picture and picture lebih efektif dibanding dengan kelompok kontrol, yaitu peserta didik yang belajar dengan model pembelajaran konvensional.

Berdasarkan hasil pengujian hipotesis dapat diketahui bahwa hipotesis yang diajukan dalam penelitian ini diterima dan terbukti. Bahwasanya, penelitian tentang "efektivitas model pembelajaran kooperatif tipe picture and picture dalam keterampilan menulis teks berita peserta didik kelas VII MTs AIIkhlas Pemetung Basuki tahun pelajaran 2016/2017" membuktikan bahwa memang ada perbedaan secara signifikan rata-rata hasil kemampuan menulis teks berita antara peserta didik yang diberi perlakuan dengan model pembelajaran kooperatif tipe picture and picture (kelompok eksperimen) dengan peserta didik yang tidak diberikan perlakuan (kelas kontrol). Pembelajaran keterampilan menulis teks berita dengan menggunakan model pembelajaran kooperatif tipe picture and picture lebih efektif dibandingkan dengan pembelajaran keterampilan menulis teks berita dengan model pembelajaran konvensional.

Efektivitas dari pembelajaran picture and picture terletak pada manajemen bagaimana peserta didik menentukan unsur $5 \mathrm{~W}+1 \mathrm{H}$. Melalui pembelajaran picture and picture dan tes pada saat penelitian peserta didik dituntut menentukan unsur $5 \mathrm{~W}+1 \mathrm{H}$ dan menentukan tema berita yang tepat sesuai dengan gambar yang tersedia dalam teks tes yang diberikan saat pembelajaran. Pada awal pembelajaran peserta didik masih belum menguasai materi dan menentukan topik yang tepat sesuai dengan isi berita yang ditulis.

Hal ini sangat dipengaruhi oleh kemampuan guru dalam mengelola pembelajaran picture and picture. Kesiapan mental dan kemampuan guru dalam mengkomunikasikan tujuan pembelajaran serta merancang kegiatan pembelajaran secara tepat sesuai dengan langkah-langkah pembelajaran picture and picture guna memperlancar kemampuan menulis teks berita peserta didik. Hal ini disebabkan dalam pembelajaran picture and picture, kondisi pembelajaran sangat menyenangkan dan tidak membuat peserta didik bosan dalam pembelajaran menulis teks berita. Acuan keberhasilan dalam pembelajaran bahasa Indonesia adalah peserta didik memiliki kompetensi menulis berita yang tinggi. Setelah dilakukan proses pembelajaran, baik untuk kelompok kontrol maupun kelompok eksperimen mengalami peningkatan. Berdasarkan perbandingan skor rata-rata atau mean pada kedua kelompok penelitian menunjukkan bahwa skor rata-rata eksperimen lebih tinggi dan berbeda secara signifikan dari kelompok kontrol dengan nilai harga $t_{\text {hitung }}$ dibandingkan $t_{\text {tabel }}$ dengan taraf signifikan $5 \%$ dari data tersebut dapat dilihat harga $t_{\text {hitung }}$ lebih besar dari harga $t_{\text {tabel }}(7.14>1.67)$. Dengan demikian $\mathrm{H}_{\mathrm{a}}$ diterima dan $\mathrm{H}_{0}$ ditolak, maka dapat disimpulkan bahwa pembelajaran dengan menggunakan model pembelajaran kooperatif tipe picture and picture dalam keterampilan menulis teks berita lebih efektif dibandingkan dengan menulis berita tanpa menggunakan model pembelajaran kooperatif tipe picture and picture.

Meningkatnya skor rerata menulis teks berita yang diperoleh peserta didik dengan model pembelajaran kooperatif tipe picture and picture menunjukkan bahwa peserta didik lebih mudah menulis teks berita dengan gambar. Melalui gambar ini peserta didik dapat menentukan tema atau topik dari sebuah berita. Berdasarkan penjelasan dari pengamatan proses pembelajaran menulis teks berita pada peserta didik kelompok eksperimen lebih menguasai materi yang disampaikan guru serta stimulus gambar yang ditampilkan di papan tulis sebagai rangsangan peserta didik dalam menulis teks berita. Hal ini terlihat pada hasil post-testnya menunjukkan rata-rata hasil kelompok eksperimen lebih tinggi dari pada skor rata-rata kelompok kontrol. Dengan demikian, dapat disimpulkan bahwa model pembelajaran kooperatif tipe picture and picture lebih efektif digunakan dalam pembelajaran menulis teks berita. 


\section{PENUTUP}

Pada dasarnya pembelajaran secara konvensional peserta didik cenderung pasif dan dalam memahami materi kurang maksimal. Keterlibatan peserta didik hanya sebatas mendengarkan dan mencatat materi yang diberikan. Hal tersebut tidak cukup memberikan motivasi belajar peserta didik dalam mata pelajaran Bahasa Indonesia khususnya materi menulis teks berita. Keterampilan menulis teks berita dengan menggunakan model pembelajaran kooperatif tipe picture and picture dikategorikan baik berdasarkan skor rata-rata menulis teks berita peserta didik adalah 78,82 dan data skor tertinggi 95 dan skor terendah 45 .

Model pembelajaran kooperatif tipe picture and picture dalam keterampilan menulis teks berita lebih efektif dibandingkan dengan model pembelajaran konvensional. Berdasarkan tabel Microsoft excel 2007 pada tabel 4.8 harga $t_{\text {hitung }}$ dibandingkan $t_{\text {tabel }}$ dengan taraf signifikan $5 \%$ dari data tersebut dapat dilihat harga $t_{\text {hitung }}$ lebih besar dari harga $\mathrm{t}_{\text {tabel }}(7.14>1.67)$. Dengan demikian $\mathrm{H}_{\mathrm{a}}$ diterima dan $\mathrm{H}_{0}$ ditolak. Dengan demikian dapat disimpulkan bahwa $\mathrm{H}_{\mathrm{a}}$ ditolak atau $\mathrm{Ho}$ diterima yang berarti menulis teks berita peserta didik yang diajar dengan model pembelajaran kooperatif tipe picture and picture lebih efektif dibandingkan dengan peserta didik yang diajar dengan model pembelajaran konvensional.

\section{DAFTAR PUSTAKA}

Hamid, Sholeh. 2011. Metode Edutainment Menjadikan Peserta didik Kreatif dan Nyaman di Kelas. Yogyakarta: Diva Press.

Huda, Miftahul. 2014. Mode-model Pengajaran dan Pembelajaran. Yogyakarta: Pustaka Pelajar.

Kamus Besar Bahasa Indonesia Edisi Ketiga Departemen Pendidikan Bahasa Indonesia. 2003. Jakarta: Balai Pustaka.

Kusumaningrat, Hikmat dan Purnama. 2005. Jurnalistik Teori dan Praktik. Bandung: P.T. Remaja Rosda Karya.

Nurjamal, Daeng, dkk.2011. Terampil Berbahasa. Bandung: Alfabeta.

Prasetyoningsih, Luluk Sri Agus. 2001. Menulis II. Universitas Islam Malang.

Sugiyono. 2010. Metode Penelitian Pendidikan (Pendekatan Kuantitatif, Kualitatif, dan R\&D). Jakarta: Alfabeta.

Suprijono, Agus. 2009. Cooperative Learning Teori \& Aplikasi PAIKEM. Yogyakarta: Pustaka Pelajar.

Tarigan, Henry Guntur. 2008. Menulis Sebagai Suatu Keterampilan Berbahasa. Bandung: Angkasa.

Trianto. 2007. Model-Model Pembelajaran Inovatif Berorientasi Konstruktivistik. Jakarta: Prestasi Pustaka.

Wahyuni, Sri dan Abd Syukur Ibrahim. 2012. Asesmen pembelajaran Bahasa. Bandung: PT Refika Aditama. 